\title{
Legal Framework for Marine Oil Pollution Control in Tanzania
}

\author{
Tumaini Shabani Gurumo \\ Dar es Salaam Maritime Institute \\ Tanzania, East Africa.
}

\begin{abstract}
Tanzania is among the countries in the west of the Indian Ocean. The country is endowed with maritime resources and a considerable coastline of about 1500 Kilometers. The well being of people leaving along the coast depend on the use of resources of the ocean. The country is facing current and potential danger of marine oil pollution caused by ships calling its ports and terminals, ships using the West Indian Ocean route, land based activities, and the developments in offshore oil and gas activities in the country and within East Africa region. In order to achieve sustainable use of the oceans and its resource, this article provide a legal framework for marine oil pollution control in the context of prevention of oil pollution, response to marine pollution incident and compensation for oil pollution damage. Specifically, the article assesses national legislation in the light of international agreements. The article assists in the analysis of the established legal regime and institutional framework for purposes of improving the status of marine oil pollution control.
\end{abstract}

Keywords: Marine pollution, Oil pollution, Oil pollution prevention, Oil pollution control.

\section{INTRODUCTION}

Tanzania population as at year 2016 is estimated at 50.1 million people, $97 \%$ from Tanzania mainland and 2.9 from Tanzania Zanzibar [1]. About 12.6 million people live within ten regions that are located along the 1500 kilometers west coast of the Indian Ocean[1]. The population of most of the coastal regions depend on the use of marine resources for food and livelihood. Fishing, tourism and sea weed farming are among activities of the coastal population[2].

Along the Indian Ocean coast there are eight major ports. Dar es Salaam Port, Mtwara Port and Tanga Port are situated at Tanzania Mainland while Malindi Port, Mkoani Port, Mkokotoni Port, Wete Port, and Wesha Port are in Tanzania Zanzibar. Tanzania ports provide services for Tanzania and other countries like Uganda, Rwanda, Zambia, Malawi, Burundi, and Democratic Republic of Congo. Crude Oil and petroleum products are among bulk liquid cargo handled by the ports and terminals.

Although there is no record of massive marine oil spill in Tanzania waters, oil leakage from motor vehicles, refineries and industries disposal has been entering the ocean from land[3]. Some oil has been entering the oceans through discharge of oil cargo at ports or terminals. Approximately 5.4 million cubic feet of oil in volume has been received in the year 2016[1]. On top of that, geographical position of Tanzania waters, put the country in the high risk of oil pollution from ships passing through the dedicated shipping route. Besides, there is evidence of the presence of oil in Tanzania waters[4]. The current increase in oil and gas activities in the region raise the risk of marine oil pollution in the country despite being a positive trend towards socio-economic development of the country. 
Marine oil pollution can cause huge damage to marine environment and negatively impact human health and the economy of the country. Since Tanzania National Vision 2025 aims at graduating the economy of the country to middle income by the year 2025 [5], this paper address legal issues pertaining marine oil pollution in order to avoid risks of economic set back. This paper address marine oil pollution control in the context of prevention of marine oil pollution, response to marine oil pollution incident and compensation for oil pollution damage deriving from the international agreements perspective.

\section{INTERNATIONAL AGREEMENTS ON MARINE OIL POLLUTION CONTROL}

Despite being useful for propelling ships, oil is an important source of energy ashore. Most oil especially crude oil and petroleum products are being transported across the oceans by using oil tankers that are specialized ships for carriage of liquid bulk cargo. According to the United Nations Conference on Trade and Development (UNCTAD) in the year 2015 transport of crude oil, petroleum products and gas accounted for about thirty per cent of total seaborne trade volume[6].

The use of oil for propelling the ship and transportation of oil cargo by sea is a source of marine oil pollution and by 1954, oil became the foremost ship source pollutant. With time there has been established international legal regime to control marine oil pollution. Accordingly, in this paper the international legal regime relating to ship source oil pollution is discussed under three categories: prevention of marine oil pollution, response to marine pollution incident, and liability and compensation for oil pollution damage.

\section{Prevention of Marine Oil Pollution}

There are a number of international conventions that are regulatory in nature, and are directly devoted to the prevention of oil pollution from happening as the first step in the protection of marine environment.

\section{The United Nations Convention on the Law of the Sea, (UNCLOS) 1982}

The UNCLOS 1982 entered into force on 16 November 1994, about 12 years after its adoption. This convention is referred to as the constitution for the oceans as it establishes a legal framework for the regulation of maritime activities in an integrated and comprehensive approach; organizes and apportions ocean space, and allocates jurisdiction over the space and the activities[7]. Iimportantly, the 1982 UNCLOS dedicates all Articles under Part XII to the protection and preservation of the marine environment.

Under the UNCLOS 1982, states are called upon to take measures as necessary to prevent, reduce or control pollution of the marine environment either individually or jointly. Such measures shall include, inter alia, minimizing pollution from vessels and pollution from installations and devices used in exploration or exploitation of natural resources of the seabed and subsoil. Such measures should protect and preserve rare or fragile ecosystems, habitat of depleted, threatened or endangered species and other forms of marine life.

Port states, flag states, and coastal states are responsible for enforcements of standards and regulations for ship source pollution. Additionally, convention calls for monetary penalty in respect of violations of national laws and regulations or applicable international rules and standards for the prevention, reduction and control pollution of marine environment. Monetary penalties may be imposed with respect to violations committed by foreign vessels beyond the territorial sea, except in case of willful and serious act of pollution in the territorial sea. 
The UNCLOS 1982 sets general principles on the protection and preservation of marine environment and therefore, with reference to Articles 211,199, 229, and235 the Convention has crossing points with the International Convention for the Prevention of Pollution from Ships 73/78, International Convention on Oil Pollution Preparedness, Response and Cooperation, 1990, the International Convention on Civil Liability for Bunker Oil Pollution Damage, 2001 and the international liability and compensation regime for oil pollution damage.

\section{The International Convention for the Prevention of Pollution of the Sea by Oil, (OILPOL) 1954}

Oil pollution from ships was first recognized as a problem during World War I, but it was not until 1954 when it was recognized as major marine pollutant caused by ships. The International Convention for the Prevention of Pollution of the Sea by Oil was adopted in 1954 and entered into force in 1958. The Convention underwent through several amendments in 1962, 1969 and 1971. The Convention concentrated on operational oil pollution from merchant ships by setting standards to reduce or eliminate pollution caused by operations of the ship such as disposal of ballast water direct to the sea with remains of oil from oil cargo tanks. OILPOL 1954 was the first international treaty designed exclusively for ship source oil pollution and therefore makes oil pollution to be the first pollutant for which international control standards were set [8].

\section{The International Convention for the Prevention of Pollution from Ships, (MARPOL) 1973 178}

The International Convention for the Prevention of Pollution from Ships 1973 was adopted on 2 November 1973 under the auspices of the International Maritime Organization (IM0), and was modified by the Protocol of 1978 (MARPOL 73/78). This is the main international convention addressing comprehensively the prevention of pollution of marine environment by ships. The convention is intended to regulate all forms of intentional pollution of the sea from ships, other than dumping. Introduction of special areas, port state control, reception facilities, record books and plans, survey and certification are among its salient features.

MARPOL 73/78 superseded the International Convention for the Prevention of Pollution of the Sea by Oil, 1954. Detailed pollution standards are set out in its six Annexes. Annex I concerns with Regulations for the Prevention of Pollution by Oil. The regulations pertaining to oil pollution address detailed technical matters in relation to prevention of pollution by oil from operational measures as well as from accidental discharges from ships. In particular, there are requirements for machinery space for all ships, construction, equipments, requirements for oil cargo area for oil tankers. Standards of survey and certification are also clearly stipulated. On the part of contracting States, they have obligation to provide reception facilities in their ports where ships can discharge the oily residues.

\section{Response to Marine Pollution Incident}

Although there are preventive conventions that are implemented by state parties and nonstate parties to the conventions, oil spills do occur thus necessity for other conventions that are dedicated to regulate response in case of marine pollution incident. Such conventions are important in mitigation of damage in case of oil pollution at sea.

\section{International Convention Relating to Intervention on the High Seas in Cases of Oil Pollution Casualties, (Intervention Convention) 1969}

Intervention Convention was adopted in 1969 and entered into force in 1975. The purpose for the adoption of the Convention was to afford states the right to protect the interests of their peoples against grave consequences of marine oil pollution as a result of a maritime casualty. 
The coming into force of the Intervention Convention 1969 availed state parties the right to take measures on the high seas that may be necessary to prevent, mitigate or eliminate grave and imminent danger to their coastline or related interests from pollution or threat of pollution of the sea by oil, following a maritime casualty. State may take such measures on the high seas only where major harmful consequences are reasonably expected. Therefore, coastal State may take action for the protection of marine environment even when casualty happens outside maritime zones under state jurisdiction.

Traditional international legal principles did not permit interference in the legitimate operation of vessel on the high seas. Coastal states had unfettered sovereignty to take measures in the territorial sea or even the exclusive economic zone whenever it consider appropriate to prevent or reduce pollution from a troubled vessel[8][9]. However, the coastal state could not take any measures if an accident occurred in the high seas, as it was outside sovereignty of the coastal State.

\section{International Convention on Oil Pollution Preparedness, Response and Co-operation, (OPRC) 1990}

The International Convention on Oil Pollution Preparedness, Response and Co-operation 1990 came into force in 1995. The Convention address the need to preserve marine environment. In particular the Convention stresses on the importance of precautionary measures and effective preparation for combating oil pollution incidents involving ships, offshore units, sea ports and oil handling facilities. The objective of the Convention is to preserve marine environment, to minimize damage to marine environment through prompt and effective actions.

With the aim to provide a global framework for international cooperation in combating major incidents and threats of marine pollution, the OPRC1990 requires ships to carry shipboard oil pollution emergency plan, operators of offshore units to have oil pollution emergency plan or similar arrangements for prompt and effective response to oil pollution incidents. Since marine pollution issues demand international cooperation, state parties are urged to take all appropriate measures in accordance with the provisions of the Convention to prepare for, and respond to, oil pollution incidents. Appropriate measures can be taken individually or Besides, the Convention sets out requirements for mutual assistance in matters such as the exchange of reports on incidents of significance that may affect the marine environment; research and development on combating oil pollution.

\section{Liability and compensation for oil pollution damage}

Notwithstanding the application of preventive measures and mitigating factors, oil spills causes damage to the environment, persons and property. According to the UNCLOS 1982 states have obligation to ensure that recourse is available in accordance with national legal system for prompt and adequate compensation or other relief in respect of damage caused by pollution of the marine environment by natural or juridical persons under their jurisdiction. Civil liability conventions are remedial in nature thus they provide protection for the rights of users of the sea and its amenities from spills of persistent oil spills from tankers[10].

At first the oil pollution liability and compensation regime comprised of International Convention on Civil Liability for Oil Pollution Damage, (CLC) 1969 and the International Convention on the Establishment of an International Fund for Compensation for Oil Pollution Damage, (Fund Convention) 1971[11]. 
The primary goal of liability and compensation conventions is to ensure that the victims of environmental damage are protected. To ensure realization of the goals of the liability and compensation regime there are provisions for compulsory insurance by the owner of the ship and victims of oil pollution damage have direct access to claim against the insurer of the ship.

The civil liability and compensation regime for oil pollution damage has also been providing remedy for restoration of marine environment and providing compensation for measures taken to prevent or minimize damage to the marine environment in a rather limited manner through compensation for impairment of environment.

\section{International Convention on Civil Liability for Oil Pollution Damage, (CLC) 1992}

The CLC 1992 is the amendment of the International Convention on Civil Liability for Oil Pollution Damage, (CLC) 1969. The basis of liability under the Convention is strict liability, therefore, the ship-owner is liable for any pollution damage caused by the oil even if there was no fault on the part of the ship or its crew. Under CLC 1992 owners of ships carrying more than 2,000 tonnes of oil as cargo in bulk, are obliged to maintain insurance to cover its liability.

Any claims for pollution damage under the CLC 1992 can be made only against the registered owner of the ship concerned. Claimants under this Convention have a right of direct action against the insurer. The ship-owner may be exempted from liability if they prove that the damage resulted from an act of war or a natural phenomenon, it was caused as a result of a third party acting with intent to cause damage or through the failure of navigational aids due to negligence of any responsible government/authority.

The CLC 1992 provides the first tier of compensation which is paid by the owner of a ship which causes pollution damage[11].

\section{International Convention on the Establishment of an International Fund for Compensation for Oil Pollution Damage, (Fund Convention) 1992}

The Fund Convention 1992 is the amendment of the International Convention on Civil Liability for Oil Pollution Damage, (Fund Convention) 1969. The Fund Convention 1992 provides a second tier of compensation when the damage exceeds the limit of the ship-owner's liability under the CLC 1992 thus the funds are insufficient. The funds under this Convention are also useful when the ship-owner is exempt from liability or is financially incapable of meeting their obligations under the CLC1992.

Contributions to the fund are levied on any person who has received after sea transport in one calendar year more than 150,000 tonnes of crude oil and/ or heavy fuel oil in a Member State of the Fund Convention 1992.

\section{Protocol of 2003 to amend the International Convention on the Establishment of an International Fund Compensation for Oil Pollution Damage 1992, (Supplementary Fund) 2003}

Supplementary Fund was adopted in 2003 as a stand-alone protocol and it entered into force in 2005. The Supplementary Fund provides additional fund for compensation beyond the available limits under the Fund Convention 1992 in States which are also Parties to the Protocol. Contributions to the fund are levied on any person who has received after sea transport in one calendar year at least 1 million tonnes of crude oil and/ or heavy fuel oil in a Member State of the Fund Convention 1992. 
It is submitted that it is better to prevent than to cure the mischief once it happens. This can be reflected in the international legal regime for oil pollution caused by ships as preventive conventions were adopted long before compensation conventions came into existence. Measures to prevent marine oil pollution should come before compensation measures.

\section{LEGISLATION ON MARINE OIL POLLUTION CONTROL}

Tanzania is a party to a number of international conventions on marine oil pollution control including: the United Nations Convention on the Law of the Sea, 1982; the International Convention for the Prevention of Pollution from Ships, 1973 /78; the International Convention Relating to Intervention on the High Seas in Cases of Oil Pollution Casualties, 1969; the International Convention on Oil Pollution Preparedness, Response and Co-operation, 1990; the International Convention on Civil Liability for Oil Pollution Damage, 1992; and the International Convention on the Establishment of an International Fund for Compensation for Oil Pollution Damage, 1992.

After a convention is ratified or acceded by Tanzania, it must be incorporated into the system of the laws of Tanzania in order to have legal effect. International Conventions are incorporated through national legal system through enactment of new legislation or an amendment to the existing national legislation. Usually, drafting instructions are prepared by experts in the relevant fields and submitted to the draftsmen. The draft is presented by the Clerk of the National Assembly as a Bill and assign it to the appropriate Standing Committee. At the second reading of the Bill, detailed explanation about the bill are given to the Assembly and it is debated. The third time the Bill is before the Assembly, the members are requested to approve the Bill and thus it is either adopted or rejected. After the Bill is passed it is submitted to the President of the United Republic of Tanzania for his assent. The assented bill becomes Act of Parliament. Upon relevant Minister's Notice in the Gazette, the Act of Parliament becomes operational. In this case of marine oil pollution control, International conventions are implemented mainly through relevant provisions in the Merchant Shipping Act, 2003 and its Regulations. Also, in Tanzania Zanzibar, the Maritime Transport Act, 2006 is applicable.

\section{The Merchant Shipping Act, 2003}

The Merchant Shipping Act No.21 of 2003 (MSA 2003) has dedicated provisions of Part XIX (sections 367-381) of the Act for Prevention of Pollution. It is provided that this part of the Act shall apply to prescribed tankers, other ships and to offshore installations. This part of the Act reflects on the International Conventions relating to the control of oil pollution at sea.

\section{Prohibition of discharge of oil}

Under the MSA 2003, sections 369 prohibits discharge of oil or oily mixture within prohibited zones, within Tanzania waters while en route from port or place within Tanzania, and anywhere at sea within Tanzania waters. Section 370 provides for allowable discharge of oil and oily mixture. It is provided that discharge of oil and oily mixture may be allowed: for purposes of safety of the ship, saving life at sea or protect ship and cargo; in case of escape or unavoidable leakage of oil or oily mixture where reasonable precautionary measures have been taken to avoid damage; far from land in case of discharge of residue that arise from the purification or clarification of fuel oil or lubricating oil; in case it is oily mixture that contain no oil other than lubricating oil which has drained or leaked from the machinery spaces in the ship. 


\section{Equipment and monitoring}

For the purposes of preventing or reducing discharge of oil and oily mixture, Tanzanian ships shall be fitted with special equipments and comply with stipulated requirements. Oil record book shall be maintained on board every Tanzanian tanker and every other Tanzanian ship which uses oil as fuel. At any reasonable time, onboard ship inspections may be done to ensure compliance provisions on protection of marine environment. Specifically, to ensure compliance with prohibitions, restrictions and obligations; to ensure adequacy of the measures to prevent escape of oil or oily mixture from the ship; ascertain contravention to the provisions of the MSA 2003; and to inspect oil record book. Contraventions by foreign ship to the relevant provisions of the MSA 2003 shall be communicated to the flag state of the ship. On the other hand, upon receiving information relating to contravention by Tanzanian ships outside Tanzania territory, the matter shall be investigated and appropriate measures be taken against the owner or master upon confirmation of the matter.

\section{Penalty for discharge}

According to section 177, the owner or master of a ship that discharge oil or oily mixture into a harbour or into the sea within 100 nautical miles from the coast of Tanzania shall be liable to a prescribed fine or to imprisonment for a term not exceeding five years or to both such fine and imprisonment. Any person liable to pay fine shall also be liable to any expense that has been incurred or will be incurred in removing pollution or making good any damage attributable to the pollution.

People are encouraged to give information to relevant authorities on matters pertaining to discharge of oil and oily mixtures into harbour or into the sea within 100 nautical miles from the coast. Any person who give information on discharge or give evidence that lead to the conviction of the ship-owner or master may be awarded at the discretion of the court that determine the matter.

\section{Liability and compensation}

The MSA 2003 channels liability for discharge or escape of oil to the owner of the ship. For the purpose of Part XIX of MSA 2003, the term oil include crude oil, fuel oil, marine diesel oil conforming to such specifications as may be prescribed, and lubricating oil. The owner/ship owner means, the registered owner and includes a demise charterer and managing owner or a managing agent in respect of a registered ship. Although liability is channeled to owner of ship, the Act provide a room for other persons to be held liable. However, these persons are not specifically mentioned. It is further provided that, liability of other persons does not make the owner of the ship discharged from own liability but will rather be equally liable.

Provisions on liability and compensation for oil pollution damage apply to any ship constructed or adopted for carriage of oil in bulk as cargo, while carrying oil in bulk as cargo or on any voyage following the carriage of oil, unless it is proved there are no residues remaining in the ship from the carriage of oil. The application involves tankers of 150 GT or more and other ships of 400 GT or more. War ships and Government ships not under commercial service are exempted from the application of Part XIX of the MSA 2003. Accordingly, for the purposes liability and compensation for oil pollution damage, ship means any sea going vessel of any type whatsoever, including floating crafts, whether self-propelled or towed by another vessel, making a sea voyage. Therefore, MSA 2003 applies to oil pollution damage caused by any ship that trade beyond internal waters of the United Republic of Tanzania or beyond the waters that the Government of the United Republic of Tanzania has declared smooth or partially smooth. Article 378 of the MSA 2003 put both foreign and domestic vessels under the application of 
CLC 1992 so long as they proceed beyond internal waters and the declared smooth or partially smooth waters.

Compensable damage includes not only damage to property and damage to environment but also any damage to any person, ecosystem or marine, caused within the United Republic of Tanzania by contamination resulting from discharge or escape. The inclusion of damage to ecosystem or marine, and any damage to person is beyond the scope of CLC 1992. Cost of any measures reasonably undertaken to prevent or minimize any damage so caused is also compensable. Furthermore, any damage caused by any measures taken for the purpose of preventing or minimizing the damage is coverable.

Furthermore, in case of grave damage caused outside the ship by reason of contamination as a result of discharge or escape of oil from ship, the owner of the ship shall be liable to pay the cost of any measures reasonably taken for the purpose of preventing or minimizing any damage within the United Republic of Tanzania and also shall be liable for any damage caused by any measures taken. The same applies even though there only arise imminent threat of damage likely to be caused outside the ship by contamination.Liability for discharge or escape of oil from ship wherever it occurs shall be incurred irrespective of whether or not the ship carried oil in cargo tank or as bunkers in the fuel tanks.

Owner of a ship shall be exempted from liability if proves that the discharge, escape or threat of contamination either resulted from act of war, hostility, insurrection or an act of God, or occurred as a result of an act done or omitted to be done by a third person other than servant or agent of the owner. The act must have been done with intent to do damage to the ship. Jurisdiction to entertain issues of liability for oil pollution is vested in the High Court of Tanzania.

Regarding provisions implementing liability and compensation conventions, some fundamental elements of liability and compensation are not addressed in the MSA 2003. There is no precise provisions pertaining to compulsory insurance, The right of victim of pollution damage to bring action direct against the insurer, together with corresponding right to the insurer to defend that damage was ship owner's willful misconduct are not taken into consideration. Limits of liability issues are not precise but rather the ship owner is expected to meet all his obligations under this part of the Act. Additionally, the Act is silent on the issue of contribution of oil importers to the Fund Convention 1992.

\section{Merchant Shipping (Prevention of Oil Pollution) Regulations, 2012}

The Merchant Shipping (Prevention of Oil Pollution) Regulations, 2012 provide technical and detailed guidelines for prevention of marine oil pollution. The Regulations apply to Tanzanian ships, ships other than Tanzania ships while within Tanzanian territorial waters, and government ships registered in Tanzania or are held in Tanzania for purposes of government.

\section{Survey and Certification}

Tanzanian oil tanker of 150 GT and above and other ship of 400 GT and above shall be subject to survey before the ship is put to service or before International Oil Pollution Prevention Certificate or Tanzania Oil Pollution Prevention Certificate is issued. There are several other survey to be performed during the five years life of the issued certificate. The ship-owner and the master of the ship are responsible for maintenance of the condition of the ship and its equipment in conformity with the Regulations. There shall not be made any alterations to the 
ship after being surveyed without approval of the relevant authority. In case of accident, it shall be reported at the earliest opportunity.

\section{Control of Operational Oil Pollution}

Details on how to discharge oil or oily mixture; oil filtering equipment; and discharge control system are clearly stipulated. Requirements for construction of tanks of new crude oil tankers as well as the existing ones are clearly stated. The use of such tanks are also a concern of the Regulations. Ships shall comply with the improved requirements for the design and construction of oil tankers with regard to protection of marine environment from oil pollution such as double hull and equivalent design.

Every oil tanker of 150 GT and above and other ship of 400 GT and above shall carry onboard a Shipboard Oil Pollution Emergency Plan prepared in the acceptable manner. The plan shall include among other thing procedure for reporting oil pollution incident, list of persons to be contacted during the incident, detailed description of action to be taken on board, and point of contact on the ship for co-ordination with national and local authorities in combating oil pollution. Such plan is important as precautionary measure to reduce and control oil pollution.

\section{Control of Oil Pollution from Offshore Installations}

It is provided that all offshore installations engaged in the exploitation, exploration and associated with offshore processing of sea bed mineral resources shall comply with the Regulations. Offshore installations include any mobile, fixed drilling, production platform used in connection with the exploration, exploitation or associated processing of sea-bed mineral resources. Such installations shall be equipped with systems and tanks required by Regulations as far as practical and keep a record of all operations involving oil and oily mixture discharges.

\section{Merchant Shipping (Oil Pollution Preparedness, Response and Co-operation) Regulations, 2012}

Merchant Shipping (Oil Pollution Preparedness, Response and Co-operation) Regulations, 2012 apply to prescribed harbours, oil handling facilities, and offshore installations. In accordance with the Regulations, offshore installations means any fixed or floating offshore structure engaged in gas, oil exploration, production activities and loading or unloading of oil.

\section{Oil Pollution Emergency Plan}

It is mandatory for harbour authorities, operators of oil handling facilities and operators of offshore installations to have in place Oil pollution emergency plan as prescribed in the Regulations. Each harbour authority, operator of oil handling facility and operator of offshore installation shall have own separate Oil pollution emergency plan. The Regulations allow for establishment of a joint plans between harbour and oil handling facility situated within a certain area or between offshore installation and oil handling facility with associated pipelines. The plan shall be approved by the relevant authority.

The plan is subject to review at least once in five years period. In case of major changes of the harbour, oil handling facility or offshore installation, a new plan shall be submitted to the relevant authority for a fresh approval. The approved Oil pollution emergency plan shall be implemented in the event of oil pollution incident.

\section{Reporting of Pollution Incidents}

Master of Tanzanian ship is responsible to report without delay to the relevant authority event involving discharge of oil at sea from his ship or any other ship or offshore installation within Tanzania waters or elsewhere. Persons in charge of offshore installation or oil handling facility 
which is pipelined are responsible to report any event involving discharge of oil at sea from another installation or ship. Also, harbour master or other persons in charge oil handling facility shall report any probable discharge of oil or presence of oil at sea.

Offshore installations or oil handling facilities are subject to inspections to ensure compliance with the Regulations.

\section{offences}

It is an offence under the Regulations for any person to fail to report an incident as required in the Regulations without reasonable cause. Upon conviction, the person shall be liable to prescribed fine.

\section{The National Marine Oil Spill Response Contingency Plan, 2016}

National Marine Oil Spill Response Contingency Plan is national response to the requirement of the OPRC 1990 for state parties to develop and manage a national response plan for oil pollution damage. Therefore, the plan was developed to ensure a timely, measured and effective response to marine oil pollution incident[13]. Under the plan, the ship owner, Master of the ship, offshore installation operators and harbour authorities bear the core function to ensure clean oceans. It is worthy to note that the plan covers oil pollution response to the lakes and rivers but does not cover response to oil pollution originating from land based sources.

\section{National Marine Pollution Control}

National marine pollution control organization set up show that that Maritime Rescue Coordination Centre (MRCC) shall be the focal point for receiving all reports of accidents and observed pollution at sea, and be responsible for operational response to oil pollution related incidents. National Marine Oil Spill Coordinating Committee (NMOSCC) manage preparedness to response to marine pollution and oversee the preparation, training and exercise for stakeholders. At the top, all matters related to marine oil pollution operations and policy falls under the responsibilities of the Minister responsible for shipping.

\section{National Marine Oil Spill Coordinating Committee}

National Marine Oil Spill Coordinating Committee comprise of representatives from all government bodies with input to marine pollution response. Such bodies include the Office of the Vice President, Office of the First Vice President Zanzibar, Ministry responsible for shipping, Zanzibar Disaster Management Department, National Environment Management Council, Surface and Marine Transport Regulatory Authority. Navy, Police Marine Unit, Tanzania Ports Authority and Zanzibar Ports Authority[12].

Other important stakeholders include but not limited to Ministry responsible for Health, Tanzania Petroleum Development Corporation, Tanzania Meteorological Agency, Fire and Rescue Force, Ministry responsible for fisheries, Dar es Salaam Maritime Institute and Institute of Marine Sciences. Each of the above mentioned institution has a role to play in the protection of human life, property and marine environment.

\section{CONCLUSION}

Tanzania is a party to a number of international conventions that address matters concerning marine oil pollution. In order to ensure such conventions are successfully applied in the country, there are enacted national legislation. The Merchant shipping Act, 2003 is the major national legislation dedicated specifically to maritime matters. Marine oil pollution is among maritime matters that are regulated by the Merchant Shipping Act, 2003. Overall responsibility for marine oil pollution lies on the Ministry responsible for shipping. 
Provisions of the Merchant Shipping Act, 2003 its Regulations in relation to marine oil pollution implement relevant international convention such as UNCLOS 1982, MARPOL 73/37, OPRC 1990, CLC 1992 and Fund Convention 1992. UNCLOS 1982 afford the country the right and duty to take measures to reduce and control pollution from vessels and installation. Through MARPOL 73/78 the country lay down marine oil pollution control system from the time of designing the vessel, through construction to the operation. There are established offences and penalties for non compliance, and rewards for taking responsibility for the protection of marine environment. Under the umbrella of OPRC 1990, oil pollution response plan is established from the level of ship owner, operators and harbour master to national level. In case of damage to marine environment, people and property, provisions of the Act that implement CLC 1992 cover for clean up and economical loss. There is also provided a room to claim under the Fund Convention 1992.

Enacting national legislation for marine oil pollution control and establishment of plan for the same is a step towards sustainable use of the oceans. Nevertheless, there is a long way to achieve the desired goal through compliance. Stakeholders at all levels must play their part and together will ensure clean oceans.

Maritime oil pollution incidents are a concern of the society and most of the time comes with political concerns, therefore, strong management of maritime matters together with proper coordination among institutions and other stakeholders is paramount for success. Enforcement institutions must be furnished with required infrastructure and facilities, experts and adequately be funded. All has been said but without dedicated maritime policy and strategy it will take longer time to realize how far back the country is lagging with reference to maritime matters.

\section{References}

Taarifa ya Hali ya Uchumi, 2016, Dar es Salaam, Tanzania: p.118;p.125, p. 248

The Status of Marine Turtles in the United Republic of Tanzania, East Africa, 2005: p.4

Mohammed, S.M., The Assessment of Water Quality and Pollution in Tanzania: p. 8

Martin, A., Lessons Learned from the Nairobi Convention, MMP Analytical Paper: p.48

http://www1.udel.edu/MAST/873/AP\%20Proposals/Alexis\%20Martin-AP\%20Final\%20Paper.pdf (09 June 2017)

Tanzania National Development Vision 2025, United Republic of Tanzania.

UNCTAD Review of Maritime Transport 2016, United Nations Publication, New York and Geneva, 2006:p. 6

Corell, H. 'The Law of the Sea and the IOPC Funds', in The IOPC Funds' 25 Years of Compensating Victims of Oil Pollution Incident, (Kent, UK.: Impact PR and Design Limited, 2003): p. 33.

Churchill, R.R. and Lowe, A.V. The Law of the Sea, $3^{\text {rd }}$ edition ,(Manchester: Manchester University Press, 1988):p. $339 ;$ p. 353

Gold, E. et al, Maritime Law (Canada: Irwin Law, 2004): p. 673

Gurumo, T. and Lixin, H. Petroleum and Sustainable Development: The Role of International Conventions, 2011 International Conference on Petroleum and Sustainable Development, IPCBEE vol. 26 (2011) (C) (2011) IACSIT Press, Singapore: p. 62.

International Oil Pollution Compensation Fund Annual Report 2016: p.9

The National Marine Oil Spill Response Contingency Plan, Septemba 2016, The United Republic of Tanzania. 